\title{
KERAJINAN PERAK TINJAUAN PADA PROSES DAN MAKNA SIMBOLIS ORNAMEN DI HOME INDUSTRY DI KOTO GADANG
}

\author{
M. Nas rul Kamal \\ Jurusan Seni Rupa Fakultas Bahasa dan Seni \\ Universitas Negeri Padang \\ Jl. Prof. Dr. Hamka, Air Tawar Padang, Kel. Air Tawar Barat, Kec. Padang Utara, Kota Padang, Kode Pos 25171 \\ Sumatera Barat. Indonesia \\ Email:2lamaknyo@gmail.com
}

\begin{abstract}
Abstrak
Tulisan ini bertujuan untuk mengetahui secara mendalamdan mendeskripsikan tentang kerajinan perak pada home Industry di Koto Gadang ditinjau dari proses dan makna simbolis ornamen dengan metode dis kriptif kualitatif. Tulisan ini dengan obyeknya difokuskan pada permasalahan y ang berkaitan dengan proses dan makna simbolis ornamen. Data yang diperoleh meng gunakan metode observasi, wawancara, dan dokumentasi dari beberapa sumber informan yang kompeten sesuai bidangnya. Keabsahan data diperoleh melaluiketekunan pengamatan, triangulasi metode dan sumber. Hasil tulisan ini adalah: (1) Proses pekerjaan (meliputi; persiapan alat dan bahan), proses dasar, (meliput; memadukan perak), pembuatan ornamen (meliputi; sket, desain, pembuatan mal, dan penaikan perak), teknik (meliputi; patri, tempa dan jalin.). (2) Makna simbolis ornamen terdapat 3 bentuk y aitu ornamen utama, pelengkap dan isian. Ornamen utama yaitu ornamen bunga mawar (melambangkan cinta kasih), ornamen pelengkap meliputi; ornamen bunga melati (melambangkan kesucian hati), ornamen bunga matahari (melambangkan kehidupan), ornamen daun asam (melambangkan kelengkapan kesempurnaan), ornamen rago/bola juga (melambangkan adanya penyatuan jalan dan roda kehidupan yang bergerak dinamis), ornamen bunga cengkeh (melambangkan kekuatan, keberkahan, kemakmuran, dan keagungan), ornamen burung (melambangkan kegagahan dan kelembutan), ornamen daun nangka (melambangkan kemegahan), dan relung (melambangkan kesetiaan).
\end{abstract}

Kata Kunci: makna, proses, simbolis ornamen, perak.

\begin{abstract}
This paper aims to find out in depth and describe about silver handicrafts in the home ind ustry in Koto Gadang in terms process and symbolicmeaning ofornament. This research is a qualitative descriptive research with the object of research on silver crafts. The research is focused on problems related to the process and symbolic meaning of ornament. The data obtained uses the method of observation, interviews, and documentation from several competent informant sources according to their fields. The validity of the data was obtained through persistence of observations, triangulation of methods and sources. The results of this study are: (1) the work process, includes: work process (including: preparation of tools and materials), basic process (includes: blending silver), ornament making (including: sketch, design, mall making, and silver raising), technique (including: solder, forge, and braid). (2) There are 3 forms of symbolic meaning, namely main ornament, complementary, and stuffing. The main ornament is a rose ornament (symbolizing love), complementary ornaments (include: jasmine flower ornaments ( symbolizing purity of heart), ornament sunflower (symbolizes life), Asam leafornament (symbolizes completeness of perfection), the rago/ball ornament also (symbolizes the unification of the road and the moving wheel of life), clove flower ornamental (symbolizes strength, blessings, prosperity and greatness) Bird ornament ( symbolizes grace and tenderness), jackfruit leaf ornament ( symbolizes splendor), niche (symbolizes loyalty). .
\end{abstract}

Keywords: meaning, process, symbolic 's ornament, silversmith..

\section{PENDAHULUAN}

Negara Indonesia kaya dengan budayanya salah satunya di Sumatera Barat, keanekaragaman budaya merupakan modal dasar bangsa untuk mengeksplorasikan menjadi sesuatu yang berguna dan bermanfaat. Bagian dari kebudayaan menonjol adalah kesenian dan teori kesenian ini dapat diungkapkan kedalam berbagai bentuk, salah satunya adalah seni kerajinan. Begitu banyak bentuk seni kerajinan yang terdapat di Sumatera Barat, dengan mempunyai karakter yang berbeda-beda seperti kerajinan logam, perak, kayu, batik, kulit, keramik, kerajinan anyam 
dengan bentuk dan keunikannya masing-masing. Namun demikian perkembangan kerajinan bukan hanya menjadi suatu alat untuk memenuhi kebutuhan sehari-hari, melainkan juga menjadi produk yang bernilai seni. Kerajinan tangan merupakan hasil keterampilan manusia, menurut Soehadji (1979: 26) sebagai berikut: yang menjadi ciri khas kerajinan adalah dihasilkan produk dengan menggunakan alat yang sederhana (manual skill), produk tersebut meliputi perabotan pemenuh kebutuhan hidup sehari-hari yang terbuat dari kayu, besi, porselin, emas, kain tenunan, gading dan batuan yang mungkin untuk diolah.Uraian tersebut, kerajinan hasil keterampilan tangan manusia yang menghasilkan karya yang dikerjakan daya cipta, skil seni secara kreatif, inovatif dan usaha yang dikerjakan secara manual. Koto Gadang salah satu daerah pengrajin yang ada di Sumatera Barat dan sekaligus pengrajin perak. Waktu kewaktu pengrajin perak ters ebut mengembangkan desain perahisan dari yang sudah ada tempat asalnya di Koto Gadang. Hingga kini satu-satunya di desa Koto Gadang yang memproduksi kerajinan perak peninggalan nenek moyang terdahulu, masih berkembang dengan baik, menurut Bambang Budi(1993: 4) menyatakan bahwa; Keahlian dalam kerajinan ini melalui proses pengalaman dan pendidikan informal. Generasigenerasi sekarang mengikuti dan mempelajari dari orang-orang yang sering mengerjakan perak sehingga lama kelamaan makin mahir dan dapat dikembangkan sendiri. Kemampuan teknis para pengrajin yang terampil bukan saja tampak dari segi ekonomi sosial, tetapi sampai pada sosial masyarakatnya juga bersemangat dan keuletan pengrajin dan kondisi tertsebut agar tidak terpengaruh oleh modernisasi.

Kerajinan perak Koto Gadang sudah menjadi khas masyarakatnya karena kerajinan ini diciptakan langsung oleh pengrajinnya yang bernilai es tetis. Nilai estetis yang sangat tinggi pada kerajinan perak dapat membuat kerajinan ini s ebagai tanda atau simbol utama kerajinan perak Koto Gadang. Keindahan ornamen yang dikandungnya memiliki makna simbolyang dapat digunakan untuk kebutuhan religius. Ornamen yang ada di Minangkabau banyak mengacu pada kes enian tradisional, dan ornamen yang dipakai dari lambang mitologi kebudayaan. Potensi kerajinan perak yang ada di Minangkabau cukup besar dan menyebar luas, karena Minangkabau merupakan salah satu di Sumatera Barat yang menjadi pusat seni kerajinan perak yang terletak di Desa di Kecamatan IV Koto, Koto Gadang Kabupaten Agamyang terpilih sebagai pusat kerajinan perak. Kerajinan perak Koto Gadang masih mempertahankan ciri khas menggunakan tangan, tanpa bantuan mesin. Namun, seiring perkembang waktu
Gorga : Jurnal Seni Rupa

Volume 09 Nomor 02 Juli-Desember 2020 p-ISSN: 2301-5942 | e-ISSN: 2580-2380

serta dinamika budaya manusia y ang bersifat dinamis, kerajinan perak diSentra Amai Setia Koto Gadang juga turut mengalami perkembangan. Perkembangan terjadi antara lain pada ornamen dan bentuk. Hal ini dilakukan oleh pengrajin agar kerajinan perak Sentra Amai Setia Koto Gadang dapat bertahan di tengah persaingan kerajinan perak di Sumatera Barat, di Indonesia dan bahkan secara global. Industri kerajinan perak Amai Setia berdiri sejak tahun 1911 sampai sekarang bisa eksis dan berkembang dengan berbagai macam produknya. Kerajinan perak home industry di Koto Gadang hanya memproduksi perhiasan seperti: cincin, leotin, tempat perhiasan, miniatur, hiasan dinding, keranjang akan tetapi juga diterapkan pada bendabenda yang mengandung makna fungsi religius seperti carano sehingga memiliki ciri ters endiri pada kerajinan perak. Dilihat dari proses dan makna simbolis ornamen yang terkandung di dalamnya merupakan bahan kajian yang menarik, untuk mengetahui proses dan makna simbolis ornamen kerajinan perak.

\section{KAJIAN TEORI}

\section{Semiotika}

Semiotika berasal bahasa Yunani yang artinya tanda, tanda itu sendiri didefinisikan sebagai kesepakatan suatu atas dasar konvensi sosial yang tergabung sebelumnya, dapat dianggap memiliki sesuatu yang lain (Sobur, 2013:95). Tanda dapat jugadijumpai pada kerajinan perak Koto Gadang serta tentang kehidupan sehari-hari dan berhubungan antar manusia; baik berupa bunyi, kata, gerak, goresan dan tanda tersebut bersifat pragmatis. Berdasarkan ruang lingkup semiotika dibedakan atas tiga macam berikut Vera (2014:4) mengungkapkan 1). Semiotika Murni(Pure). Pure semiotic membahas tentang filos ofis, yaitu berkaitan dengan metabahasa, dalam arti hakikat bahasa secara universal yang dikembangkan oleh Saussure dan pierce. 2). Semiotika Deskriptif (Descriptive). Descriptive semiotic adalah ruang lingkup semiotika yang membahas tentang semiotika tertentu, mis alnya sistem tanda tertentu atau bahasa tertentu, secara deskriptif. 3). Semiotika Terapan (Applied). Applied semiotic adalah lingkup semiotika yang membahas tentang penerapan semiotika pada bidang kerajinan perak, misalnya dengan kaitanya sis temtanda sosial, s astra, komunikas i, periklanan, dan sebagainya.

\section{Pelopor Semiotika}

Semiotika moderen ada dua orang pelopor, yaitu Charles Sanders Peirce (1839-1914) dan Ferdinand de Saussure. Sebenarnya kata semiotika tersebut telah digunakan oleh para ahli filsafat Jerman bernama Lamber. Bertolak dari pandang an semiotika tersebut, 


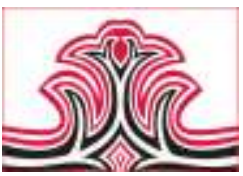

jika seluruh praktik sosial dapat dianggap sebagai fenomena bahasa, maka semuanyatermasuk bangunan pakaian, bangunan tradisi dan dapat juga dipandang sebagai tanda-tanda.

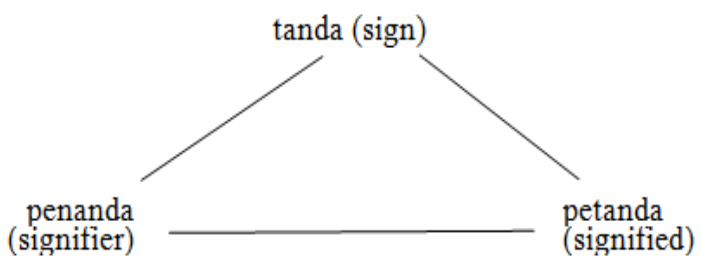

Gambar 1. Kerangka Tanda (Vera, 2014: 22)

Charles Sanders Pierce menyebutkan bahwa, menandakan hanya dapat berpikir dengan medium tanda dan manusia hanya dapat berkomunikasi lewat sarana tanda dan dapat diartikan memang gil/anggukan kepala dapat diterjemahkan setuju, tanda bunyi, seperti tiupan peluit, terompet, genderang, suara manusia dan tulis an, di antaranya huruf dan angka. Bis a juga tanda bergambar berbentuk rambu lalulintas, dan masih banyak ragamnya.

\section{Trikotomi Semiotik Pierce}

Perkembangan semiotika tidak terlepas dari teori yang dikemukakan oleh Charles Sanders Pierce yang dianggap sebagai bapak Semiotika. Tanda mempunyai dua aspek yaitu penanda dan petanda sedangkan semiotik berhubungan dengan segala sesuatu yang berhubungan dengan tanda hadir secara aktual. Pierce berpendapat bahwa tanda dibentuk melalui hubungan segitiga atau yang biasa dis ebut trikotomi atau struktur triadik Pierce.

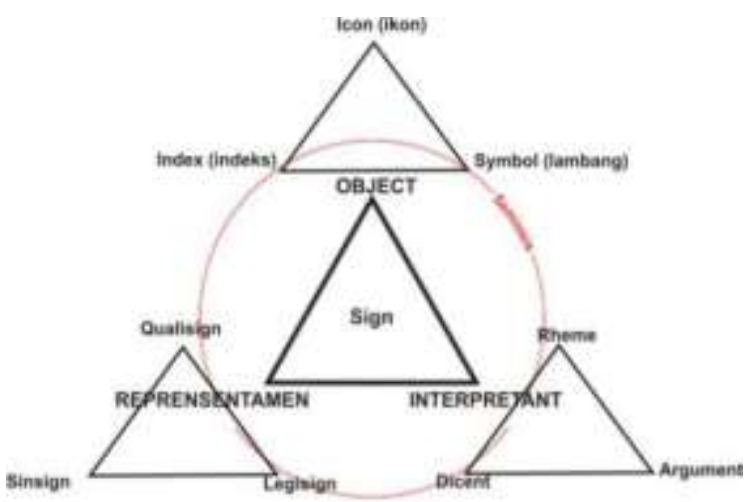

Gambar 2. Kerangka Trikotom (Vera, 2014: 22)

Grafik tersebut di atas bahwa yang dimaksud dengan "simbol, indeks, dan ikon" oleh Pierce berakar pada tanda-tanda yang pada objek yang dilihat manusia. Mengenai tanda-tanda yang disebut "singsign",
Gorga : Jurnal Seni Rupa

Volume 09 Nomor 02 Juli-Desember 2020

p-ISSN: 2301-5942 | e-ISSN: 2580-2380

"qualisgn" dan "legisign" adalah tanda-tanda yang berasal dari gambaran yang dirasakan oleh manusia (represetatemen) atau groundnya. Qualisign merupakan kualitas yang ada pada tanda, misalnya kata-kata kasar, keras, lemah, lembut, merdu. Sinsign merupakan eks istensi aktual benda atau peristiwa yang ada pada tanda, misalnya; kata kabur atau keruh yang ada pada urutan kata air sungai keruh yang menandakan bahwa ada hujan di hulu sungai. Legisign adalah norma yang dikandung oleh tanda, misalnya rambu-rambu lalu lintas yang menandakan hal-hal y ang boleh atau tidak boleh dilakukan manusia (Sobur, 2013: 41-42).

Tabel 1. Trikotomi Pierce

\begin{tabular}{|r|c|c|c|l|}
\hline 1 & $\begin{array}{c}\text { Represen- } \\
\text { tatement }\end{array}$ & Qualisign & Sinsign & Legisign \\
\hline 2 & object & Icon & Index & Symbol \\
\hline 3 & $\begin{array}{c}\text { Interpre- } \\
\text { tant }\end{array}$ & Rhema & Dicisign & Argument \\
\hline
\end{tabular}

(Vera, 2014: 23)

Berdas arkan interpretant, tanda (sign, representamen) dibagi atas rheme, dicent atau dicisign dan argument. Uraian tersebut menjelaskan bahwa dari trikotomi Pierce yang terkait dengan semiotika visual terutama tanda-tanda dari objek kerajinan perak Koto Gadang yang dapat dilihat manusia.

Tanda dapat juga berupa lambang, jika hubungantanda iłu dengan yang diwakilinya didasarkan perjanjian (Convention). Misalnya lampu merah yang mewakili larangan berdasarkan perjanjian dałam masyarakat Apa bila suatu tanda dan acuan berupa hubungan kemiripan, tanda itu dis ebut ikon. Sebuah motif hias adalah tanda yang disebut dengan ikon, karena sebuah objek seperti motif hias itu mewakili kenyataan tertentu misalanya orang berdasarkan kemiripan (Similarity). Pendapat tersebut di atas maka ikon disipulkan tanda yang menyerupai sesuatu yang diwakili ciri-ciri sama dengan apa yang dimaksudkan. Dałam seni rupa ikonisitas dapat dałam rupa yaitu: bentuk, susunan atau unsur-unsur bentuk. Kemungkinan yang lain adalah ikon-ikon struktur atau susunan, ikon warna dan tekstur.

Indeks berasal dari kata benda indexes atau indices berarti daftar kata-kata penunjuk bagi cara berpikir, contoh lain adalah penunjuk daftar kata penting pada halaman tertentu (Departemen Pendidikan Indonesia , 2011: 329). Semiotika, indeks dipakai untuk menyatakan as osiasi hubungan makna dałam tanda yang 
satu dengan makna dalam tanda yang lain, dengan syarat ada keterkaitan keduanya.

Simbol merupakan suatu tanda yang berhubungan antara tanda dan acuannya terbentuk secara kesepakatan sosial. Contoh adalah bahasa, dimana tanda-tanda dan unsur-unsur kebahasaan adalah simbol, walaupun beberapa di antaranya adalah ikon dan indeks. Berdasarkan berbagai klasifikasi tersebut, Peirce membagi tanda menjadi sepuluh jenis (Sobur, 2013: 42-43).

Semiotika Pierce tidak sepenuhnya dapat dipakai dalammenganalis is simbolis asi visualkerajinan Perak. Hal ini disebabkan sebab sistem tanda visual dapåt berobah sesuai dengan pembaca makna dan pencipta makna simbol yang disebut dengan transformasi makna seperti yang diperlihatkan.

Semiotika Saussure adalah semiotika strukturalis pada prinsip bahwa bahasa adalah s ebuah sistemtanda, dan setiap tanda itu tersusun dari dua bagian, y akni signifier (penanda) dan signified (pertanda). Tanda adalah kes atuan dari suatu bentuk penanda (signifier) dengan sebuah idea tau pertanda (signified) (Vera, 2014).

\section{METODE PENELITIAN}

Penelitian ini merupakan jenis penelitian diskriptif kualitatif yang difokuskan pada proses dan makna simbolis ornamen home industry modal kecil yang mudah dan menguntungkan. Metode pengumpulan data menggunakan wawancara, observasi, dan dokumentasi. Sehingga yang menjadi tujuan dari penelitian kualitatif ini adalah menggambarkan realita empirik dibalik fenomena secara mendalam, rinci dan secara sis tematis untuk mengumpulkan, mengolah dan menyimpulkan data, dengan metode tertentu guna kepentingan mencari jawaban atas permasalahan yang dihadapi.

Menurut Moleong (2011: 8) karakteristik penelitian kualitatif itu mempunyai ciri-ciri yaitu: latar alamiah pada tindakan pengamatan mempengaruhi apa yang dilihat, manusia sebagai alat (instrumen) yang dapat berhubungan dengan responden atau objek lain, sehingga mampu memahami kaitan kenyataankenyataan di lapangan.

\section{HASIL DAN PEMBAHASAN}

\section{Hasil}

Berdasarkan hasil interview, observasi, dan studi pustaka, Data yang diambildalampenelitian mengenai "kerajinan perak ditinjau dari proses dan makna simbolis ornamen" adalah data primer. Data primer yang dimaksud adalah data yang berasal dari sumber
Gorga : Jurnal Seni Rupa

Volume 09 Nomor 02 Juli-Desember 2020

p-ISSN: 2301-5942 | e-ISSN: 2580-2380

secara langsung, berarti penulis melakukan pencarian data yang mendatangi home industry di Koto Gadang. Data ini diperoleh dari teknik observasi, wawancara dan dokumentasi.

Pengambilan datadilaks anakan pada bu lan Juli s ampai dengan September 2019 di home industry di Koto Gadang Minangkabau. Adapun data yang diperoleh dari hasil observasi dan wawancara meliputi keterangan tentang proses dan makna simbolis ornamen, sedangkan data yang diperoleh dari hasil dokumentasi adalah sejarah, profil, proses dan makna simbolis ornamen kerajinan perak.

\section{1). Proses Perak Home Industry Koto Gadang}

Proses pembuatan finishing kerajinan perak Koto Gadang Minangkabau dibagi atas 4 tahap yaitu: persiapan, proses dasar, pembuatan ornamen, dan teknik bakar. Proses meliputi (persiapan bahan dan alat), proses dasar meliputi (pengikiran produk, pengikiran, pemolesan, dan pematrian), pembuatan ornamen meliputi (membuat sket, desain, mal, menjelaskan bidang dasar untuk memunculkan ornamen), teknik penyepuhan, meliputi pemolesan lapis an transparan. Adapun tahap pembuatan proses kerajinan perak; pembuatan ornamen dan teknik pengerjaan. Tahap pembuatan ornamen merupakan proses yang paling penting yaitu untuk mengetahui keindahan seni perhiasan yang terdapat pada benda perak. Hal ini yang menentukan kekhasan pada pengrajin kerajinan perak, juga disamping itu penentuan ornamen juga berpengaruh besar untuk produksi kerajinan perak Koto Gadang. Adapun tahaptahap yang dilakukan dalampembuatan ornamen yaitu membuat sket, desain, mengemal, dan membuat pola bidang dasar benda. Bagi pengrajin yang sudah mahir dapat langsung membuat desain di atas kertas yang akan dijadikan sebagai hiasan dengan ornamen yang diterapkan pada perhiasan.

\section{2). Teknik dalam Pembuatan Ornamen Home Industry Koto Gadang}

Teknik dalam pembuatan ornamen yang dilakukan pengrajin perak Koto Gadang menggunakan teknik yang dipakai diantaranya; cincin pria dan wanita dengan teknik digunakan yaitu: (1) teknik bakarang (kerangka), (2) teknik pahek (pahat), (3) teknik bajalin (seperti anyaman), (4) teknik kikia (mengikir), (5) teknik suntik (menempel/menekan), (6) teknik baka (membakar), (7) teknik batapuang (seperti ditekan/dipres) dan (8) teknik Tali Aia (kawat/wire). Maka pengembangan kerajinan perak pada Sentra Amai Setia Koto Gadang berada pada kategori praktis baik ditinjau dari segi kemudahan dalam penggunaan, 
manfaat yang didapat dan kesesuaian dengan perkembangan zaman dan waktu. Pembuatan ornamen setiap benda-benda pada umumnya ornamen yang hendak disket/ didesain disesuaikan dengan besar kecilnya pada permukaan benda yang buat.

Proses pembuatan ornamen tentunya dilakukan terhadap benda-benda perak yang sebelumnya sudah dioleskan bahan pewarna prada hingga kering kemudian, ornamen yang dibuat berbentuk ornamen tumbuh-tumbuhan dan hewan. Makna simbolis ornamen kerajinan perak Koto Gadang menurut Sus anto (2011: 284) Ornamen merupakan hias an yang dibuat dan digambar, dipahat maupun dicetak, untuk mendukung peningkatan kualitas dan nilai pada suatu karya seni. Ornamen juga merupakan ciri dari bagian kerajinan perak yang biasa dis ebut oleh masyarakat Minangkabau dengan penyepuhan. Penyepuhan berasal dari kata sepuh yang berarti melapisi, membersihkan, atau mengkilatkan. Ornamen-ornamen yang sering dibuatkan dalam kerajinan perak menggunakan ornamen flora dan fauna. Jenis ornamen tersebut diwariskan secara turun-temurun sehingga tidak adanya perubahan. Kedekatan kekerabatan pengrajin lain dapat menghasilkan persamaan dari beberapa unsur bentuk ornamen. Namun, meskipun terdapat bentuk-bentuk ornamen yang serupa den gan pengrajin lain, antara Silver Work dengan Silver Work memiliki perbedaan dengan teknik, warna hingga bentuk karyanya.

Ornamen yang terdapat pada benda-benda terbuat dari bahan perak ini semuanya sama, setiap pengrajin menuangkan bentuk ornamen ciri khas Minangkabau alasannya, karena untuk menjaga agar seni hias bentuk ornamen masih diingat dan dilestarikan keberadaanya. Ornamen yang diterapkan merupakan bentuk yang memiliki makna simbolis. Pengrajin perak Koto Gadang seluruhnya menggunakan ornamen flora dan fauna yang digunakan berbagai bentuk ornamen khas Minangkabau serta membuat bentuk peniruan, karena sebagai penggambaran bentuk-bentuk baru dan menuangkan keindahan yang terdapat dari bentuk tersebut. Adapun Silver work Rul dan Leo mengungkapkan bahwa, dari semua bentukyang ingin dibuat tidak harus sama dengan orang lain, dengan membuat bentuk-bentuk baru akan muncul ide penciptaan sendiri, begitu juga dengan pengrajinpengrajin perak Koto Gadang tanpa dipaksakan untuk membuat kreasi sendiri terkecuali ada pemesanan. Penciptaan ide sendiri, Silver Work-Silver Work tidak memproduksi hasil produknya melainkan hanya untuk kebutuhan pribadi, sedangkan untuk ornamen hasil peniruan bentuk lain dari kons umen membuatkan akan
Gorga : Jurnal Seni Rupa

Volume 09 Nomor 02 Juli-Desember 2020 p-ISSN: 2301-5942 | e-ISSN: 2580-2380

tetapi tidak diproduksikan secara besar-besaran, maksudnya hasil kerajinan ornamen tersebut dibatasi hanya beberapa. Apabila diproduksi secara besarbes aran dikawatirkan ornamen ciri Minangkabau yang merupakan kerajinan tradisi, dengan mudah akan menghilang karena kerajinan perak merupakan kerajinan turun-termurun maka, ornamennya juga menggunakan bentuk terdahulu. Sebagian besar jenis ornamen flora dan fauna mengacu pada bentuk as linya dan hanya ada beberapa perubahan /stilisasi pada bagian-bagian tertentu misalnya pada kelopak dan tangkai bunga. Selain dari bentuk yang menyerupai di dalamnya juga terdapat makna simbolis yang menceritakan adanya nilai prilaku, dan kehidupan. Pengrajin perak

Koto Gadang menuangkan bentuk ornamen pada benda-benda perhiasan dari ciri yang sudah menjadi ragamhias Minangkabau dengan adanya pengaruh dari budaya Melayu, Arab bahkan Jawa sehingga karakteristik bentuk ornamen Minangkabau identik dengan lajunya kebudayaan ters ebut sekarang sudah menjadi seni masyarakat Minangkabau. Ciri khas kerajinan perak Koto Gadang terletak pada teknik dan hiasan dari flora dan fauna. Ornamen kerajinan perak yang diterapkan merupakan stilisasi dari unsur-unsur yang terdapat pada alam seperti tumbuh-tumbuhan, hewan dan gabungan antara tumbuh-tumbuhan dan hewan. Selain itu juga menerapkan ornamen kreasi seperti kuda dan sepeda motor yang bukan termasuk ornamen Minangkabau, penerapan tersebut dilakukan karena pengrajin perak dari generasi sebelumnya mengungkapkan bahwa: Ornamen buah cengkeh dan daun as am awalnya tergolong ornamen Minangkabau dan sekarang banyak digunakan, karena bentuk tersebut merupakan pengaruh budaya kerajaan Pagaruyung sendiri.

Berpengaruh pula pada ornamen Minangkabau yang tidak menyebutkan adanya ornamen miniatur kuda, sepeda motor. Ungkapan tersebut adaterdapat dua jenis y ang merupakan hasil peniruan bentuk lain seperti kuda dan ikan, sedangkan yang lainnya merupakan ciri ornamen Minangkabau. Secara keseluruhan ornamen terdiri pada bagian-bagian yang mempunyai peranan berbeda satu sama yang lain. Bentuk ornamen terbagi menjadi 3 karakter yang pertama yaitu ornamen utama, ornamen pelengkap dan isian. Yang dis ebut ornamen utama adalah bentuk ornamen yang paling menonjol daribentuk ornamen yaang ada sekelilingnya atau bisa dis ebut sebagai senter of interes, sedangkan ornamen pelengkap merupakan bentuk ornamen yang berfungsi sebagai mengisi pada bidang-bidang y ang kosong serta melengkapi bentuk ornamen utama, dan isian yang 
berfungsi w3memperindah bentuk ornamen utama maupun bentuk ornamen pelengkap. Adapun bentukbentuk ornamen utama yaitu bunga mawar, ornamen pelengkap bunga melati, bunga matahari, daun dan pohon kelapa serta isian (isen-isen/taro).

\author{
Ornamen Pelengkap \\ Ornamen Bunga Melati \\ Ornamen Bunga Matahari \\ Ornamen Daun As am \\ Ornamen Daun Nangka \\ Ornamen Bunga Cengkeh \\ Ornamen Bunga Mawar.
}

\section{Pembahas an}

Eemen Estetika sering dikenal dengan istilah keindahan. Keindahan adalah nilai-nilai estetis yang menyertai sebuah karya seni. Keindahan jug a diartikan sebagai pengalaman estetis yang diperoleh ketika seseorang mencerap objek seni atau dapat pula dipahami sebagai sebuah objek yang memiliki unsur keindahan. Nilai-nilai keindahan (estetik) atau keunikan karya seni memiliki prinsip: kes atuan (unity), kes elaras an (harmony), kes eimbangan (balance), dan kontras (contrast) sehingga menimbulkan perasaan haru, nyaman, nikmat, bahagia, agung, ataupun rasa senang. Kajian estetika berdasarkan data pada kerajinan perak yang ada di Koto Gadang bentuk (form) kerajinan perak disusun dengan teknik wire (tali aia), tatah/tempa, ukir dan sebagainya. teknikini yang menjadi pembentuk karya perak koto gadang dan memberikan kesan estetis yang halus, ringan. Ekplorasi desain akan terbatas karena pengrajin perak Koto Gadang telah menguasai teknik-teknik tersebut secara turun-temurun. Kesan lain yang ditimbulkan terkesan kuno karena keselarasan dari desain ini dinilai kurang cocok dengan kebutuhan Elemen ergonomis karya fashion masa kini.

Elemen kontras dalamdesain tradisi memberikan kesan yang monoton, karena disusun dengan perak murni. Pengrajin sangat menjaga kualitas merak untuk membuat kerajinan dengan teknik tali aia, artinya teknik ini membutuhkan perak yang berkualitas untuk membuat kawat yang sangat halus tersebut. Kontras karya perak jadi kurang menonjol karena tidak dikombinasikan dengan elemen estetis yang lain seperti batu permata, s cornia, atau gemstone lainnya. Es tetika dalam seni terapan kerajinan perak bis a dikembangkan dengan proses penerapan model pengembangan kerajinan perak Koto Gadang ini dan memberikan pengetahuan yang sistematis sehingga para pengrajin memiliki motivasi dan pemahaman tentang penting seni dalam mengekplorasi desain-des ain baru.
Gorga : Jurnal Seni Rupa Volume 09 Nomor 02 Juli-Desember 2020 p-ISSN: 2301-5942 | e-ISSN: 2580-2380

Elemen Ergonomis pada kerajinan selalu dikaitkan dengan aspek fungsi dan unsur ergonomis karya sebagai berikut: 1). Keamanan (security) y aitu:jaminan tentang keamanan orang menggunakan produk kerajinan tersebut. Perhiasan yang terbuat dengan teknik tradisi memiliki bentukyang komplek sehingga susah dalam melakukan perawatan. Lekuk-lekuk dan tekstur permukaan perhiasan dapat menimbulkan timbunan kerak, kotoran, debu, bahkan sisa makanan seperti pada cincin dengan teknik tali aia. Hubungan faktor security tentu dinilai penting karena desain ters ebut akan menjadi alas an untuk tu mbuhnya bakteri, jamur, dan bisa menimbulkan luka untuk sebagian desain yang tajam atau runcing.

2).Faktor lain dari aspek keamanan adalah jumlah perak murni yang digunakan tentu berdampak pada harg a dari perhiasan tersebut. Sebagian konsumen atau pengguna perhiasan sekarang merasa kurang aman untuk menggunakan perhiasan yang berharga mahal, selain berkesan mencolok, biaya tempa yang tinggi, tentu juga menjadi pertimbangan untuk jaminan keamanan pemakai untuk berada di tempat umum.

3). Kenyamanan (comfortable) yaitu kenyamanan apabila produk kerajinan sangat dipengaruhi oleh desain yang dibuat. Bentuk ornamen desain yang runcing dan tajam, banyak lekukan, terawang pada sebagain desain tradisi menimbulkan permasalahan. Pada desain bros, kalung sering dijumpai serat kain yang menyakut, terkadang rambut pemakai perhiasan tersebut ikut ters angkut.

4). Praktis, yaitu produk kerajinan terapan adalah produk kerajinan yang memiliki nilai praktis yang tinggi. Dewasa ini, masyarakat tidak mau terlibat dengan hal yang rumit. Segala sesuatu dalamkemajuan teknologi dan globanisasi selalu menyederhanakan bentuk kerumitan dalam kehidupan sehari-hari.

5). Ruang lingkup desain yang praktis, juga mempengaruhi keinginan konsumen dalam menggunakan perhiasan da gaya desain yang minimalis mendapat tempat lebih menguntungkan, selain pengerjaan lebih mudah juga berdampak kepadaharga murah dan dikerjakan dengan teknik tradisional (handmade), dan 6). Keluwesan (flexibility), yaitu keluwesan penggunaan produk terapan/pakai, yaitu produk kerajinan yang wujudnya sesuai dengan kegunaan atau terapannya.

Ornamen Ragam Hias pada produk kerajinan dari bahan perak di Koto Gadang sangat kaya dengan keragaman produk kerajinan dengan berbagai macam 


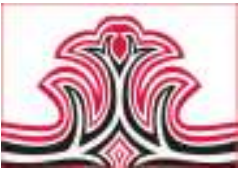

ragam hias yang tersebar dis eluruh tanah air. Ragam hias Nusantara pada umumnya memiliki muatan nilai tradisi masing-masing. Perbedaan dan persamaanya, misalnya jenis, bentuk, ornamen hias, pola susunan, pewarnaan, bahkan nilai simbolisnya.

Berbagai ornamen ragam hias yang dapat digunakan untuk menghias karya kerajinan antara lain seperti berikut. 1) Ornamen realis dirancang menurut dan berdasarkan bentuk-bentuk nyata yang ada di alam sekitar seperti bentuk tumbuh-tumbuhan, bentuk hewan atau binatang, bentuk batu-batuan, bentuk awan, matahari, bintang, bentuk pemandangan alam. Dalam tradisi Minangkabau ABS-SBK(Adat Bersandi Syarak, Syarak Bersandi Kitabullah), tidak terdapat gaya ornamen realis hal ini dipengaruhi kebudayaan is lam yang melarang penggambaran mahluk hidup. Kecendrungan ornamen lebih menonjolkan bentuk geometris atau stilis asi dari flora seperti bunga, sulursulur. Berbeda dengan fakta y ang ditemukan sekarang, masyarakat Minangkabau sudah lebih dinamis dan permisif. Alasan praktis mengikuti perkembangan zaman yang memunculkan ornamen realis. Terdapat kerajinan perak berupa kerbau dengan pedati, bangunan khas di daerah setempat (miniature), serangga, ikan, kuda, kupu-kupu dan keranjang. 2) Ornamen geometris yang mempunyai bentuk teratur dan dapat diukur menggunakan alat ukur. Contoh: bentuk segiempat, segitiga, lingkaran, kerucut, dan silinder.

Ornamen geometris merupakan ornamen tertua dalam ragam hias karena sudah dikenal sejak zaman prasejarah dan bentuk titik, garis, atau bidang yang berulang dari yang sederhana sampai deng an pola yang rumit. Hampir di seluruh wilay ah Nusantara ditemukan ornamen ini. Ornamen hias geometris dalamkerajinan perak merupakan aplikasi dari nilai tradisi, filosofi, kebudayaan tradisi Minangkabau. 3) Ornamen dekoratif ini menggambar dengan tujuan mengolah suatu permukaan benda menjadi lebih indah. Gambar dekoratif berupa gambar hias an yang perwujudannya tampak rata, kesan ruang jarak jauh dekat atau gelap terang tidak terlalu ditonjolkan. Objek gambar dekoratif, perlu dilakukan deformasi atau penstiliran alami, bentuk dan digayakan tanpa meninggalkan bentuk aslinya. 4) Ornamen abstrak yang tidak dikenali objek asalnya, y ang digambarkan atau memang benarbenar abstrak karena tidak menggambarkan objekobjek yang terdapat di alam maupun objek khayalan gubahan objek alam serta tidak menggunakan unsur tulis an yang terbaca.
Gorga : Jurnal Seni Rupa

Volume 09 Nomor 02 Juli-Desember 2020 p-ISSN: 2301-5942 | e-ISSN: 2580-2380

Ornamen abstrak di sini menggunakan bentuk yang lebih bebas, Berikut ini contoh ornamen abstrak seperti ornamen gelang maniak batapak, gelang maniak rambai, gelang induak, gelang Bangkok. Ornamen abstrak ini dinamai berdasarkan kedekatan bentukbentuk yang ada di alam. Bentuk dan jenis-jenis kerajinan perak yang dihasilkan oleh pengrajin Koto Gadang dewasa ini sangat beragam antara lain: antinganting, liontin, bross, subang, gelang, kalung, ikat pinggang, hiasan, miniatur, dan berbagai bentuk cendramata (souvenir) untuk memenuhi kebutuhan pariwis ata, baik domis tik maupun asing.

Produk kerajinan perak Koto Gadang di des ain dengan memadukan unsur-unsur ornamen tradisional Minangkabau yang sudah ada sebelumnya, dengan menyerap unsur-unsur desain modern, sehingga menghasilkan berbagai produk yang kreatif dan inovatif, yang memiliki kekhas an tersendiri, sehingga bisa bersaing di pasaran, baik lokal, nasional, maupun global. Kemampuan mengorganisasikan elemenelemen seni rupa seperti garis, bidang, warna, tektur, ruang, dan prinsip-prinsip penyusunan seperti: komposisi, proporsi, kesatuan, kontras, irama, dan keseimbangan, sangat dibutuhkan dalam membuat rancangan desain (FadjarSidik, 1981:25). desain yang inovatif memiliki dasar kreatif dalam mencermati gejala sosial, budaya, ekonomi dari masyarakat, sehingga memiliki karakteris tik atau identitas budaya. Pengrajin perak Koto Gadang Kecamatan IV Koto, Kabupaten Agam terus melakukan berbagai upaya dalam mengembangkan desain-desain baru yang kreatif dan inovatif, dalammemenuhi kebutuhan pasar pariwis ata yang sangat kompetitif.

Pemaknaan Denotasi Makna yang diwujudkan melalui keberadaan ornamen bunga mawar, kelopak bunga mawar dan Inti Sari adalah ornamen bunga mawar dalam kerajinan perhiasan mempunyai arti perlambangan sebagai cinta kasih yang harus dipertahankan. Ornamen bunga mawar diterapkan pada semua bentuk kerajinan perak Koto Gadang, karena ornamen bunga mawar merupakan ornamen utama. Salah satu jenis kerajinan perak Koto Gadang yang menerapkan ornamen bunga mawar pada kerajinan perhiasan perak. Perhiasan perak merupakan kelengkapan asesories. Perhiasan mulanya bergambar (polos) akan tetapi dengan adanya perkembangan, kerajinan perhiasan ini dihiasi dengan taro (pengisi diantara ornamen) perhisan perak Koto Gadang menggunakan ornamen bunga mawar.

Ornamen bunga mawar digunakan karena memiliki bentuk kelopak yang indah melingkar dari bagian inti 
sarinya. Ornamen bunga mawar dalam kerajinan perhiasan mempunyai arti perlambang an sebagai cinta kasih. Keterkaitan makna tersebut dilihat dari fungs in ya yang s ebagai keperluan pernikahan sehingga adany a suatu kehidupan. Bunga melati merupakan jenis tanaman bunga hias yang berupa perdu/ semak berbatang tegak y ang hidup menahun. Di Koto Gadang jenis tumbuhan ini disebut dengan bunga melati. Jenis ornamen bunga melati merupakan jenis ornamen yang tercipta setelah ornamen bunga mawar. Pada saat itu ornamen bunga melati sering diterapkan oleh pengrajin-pengrajin untuk membuat perhiasan berbagai bentuk kerajinan. Terbentuknya penciptaan ornamen bunga melati ini karena adanya suatu pernikahan adat budaya yang menggunakan bunga melati sebagai hias an pengantin wanita. Hias an tersebut kini ornamen bunga melatimelambangkan adanya "kesucian hati". Maksud dari kesucian yaitu bersifat bersih/fitrah.

Tabel 2. Elemen Ornamen Bunga Melati

\begin{tabular}{|l|l|}
\hline $\begin{array}{l}\text { Elemen-Elemen } \\
\text { Ornamen Bunga } \\
\text { Melati }\end{array}$ & Makna Simbolis \\
\hline & \\
\hline $\begin{array}{l}\text { Inti Sari } \\
\text { Kelopak Bunga } \\
\text { Mawar }\end{array}$ & $\begin{array}{l}\text { Inti sari ornamen bunga } \\
\text { melati tertutup } \\
\text { melambangkan adanya } \\
\text { kerahasian } \\
\text { melambang bunga melati } \\
\text { kelembutan }\end{array}$ \\
\hline $\begin{array}{l}\text { Tangkai bunga } \\
\text { mawar }\end{array}$ & $\begin{array}{l}\text { Tangkai bunga melati } \\
\text { berduri melambangkan } \\
\text { adanya perlindungan }\end{array}$ \\
\hline $\begin{array}{l}\text { Teknik } \\
\text { pengerjanya }\end{array}$ & Bakarang dan jalin \\
\hline
\end{tabular}

Bunga melati salah satu jenis dari beberapa tumbuhan yang sering digunakan pada ornamen kerajinan perak. Ornamen bunga melati hampir sama seperti bunga mawar memiliki arti dan makna bagi masyarakat Minangkabau lambang tersebut digunakan pada saat adany apernikahan. Keberadaan ornamen bungamelati di Koto Gadang sampai saat ini mas ih sering diterapkan pada kerajinan lainnya. Hal ini menyebabkan karena ornamen bunga melati sangat berpengaruh besar terhadapnilai kebuday aan Minangkabau, khususnya di daerah Koto Gadang. Ornamen bunga melati ini juga termasuk ciri ornamen Koto Gadang.
Gorga : Jurnal Seni Rupa

Volume 09 Nomor 02 Juli-Desember 2020

p-ISSN: 2301-5942 | e-ISSN: 2580-2380

Makna ornamen bunga melati melambangkan keberanian, maksud dari keberanian yaitu adanya keyakinan dan kekuatan dalam kehidupan. Ornamen bunga melati memiliki beberapa karakteristik diantaranyamemiliki kelopakbunga y ang mengelilingi benang sari yang berbentuk s eperti mahkota, memiliki tangkai dan berduri serta pada bagian pusatnya terdapat inti sari. Ornamen utama menjadi sangat penting diantara ornamen pelengkap, karena ornamen utama merupakan bentuk yang memiliki daya tarik tersendiri. Pada kerajinan perak penerapan tumbuh-tumbuhan, binatang maupun gabungan semuanya sama sesuai dengan permukaan bentuk benda yang diinginkan, sedangkan pelengkap dan isian berfungsi untuk menghiasi ornamen utama agar terlihat lebih menarik. Bentuk ornamen yang terdapat dalams atu jenis produk tidak hanya terdiri dari satu bentuk tetapi ada yang merupakan kombinasi antar dua atau tiga. Penempatan bentuk ornamen tersebut bersifat bebas sesuai besar kecilny a bidang bendayang akan dihias. Bentuk bunga yang diterapkan pada ornamen perak merupakan penciptaan dari tumbuh-tumbuhan. Juga berbagai jenis tumbuhan bunga, yang menjadi salah satu pemilihan dalam penerapannya adalah ornamen bunga melati.

Tabel 3. Elemen Ornamen Bunga Matahari

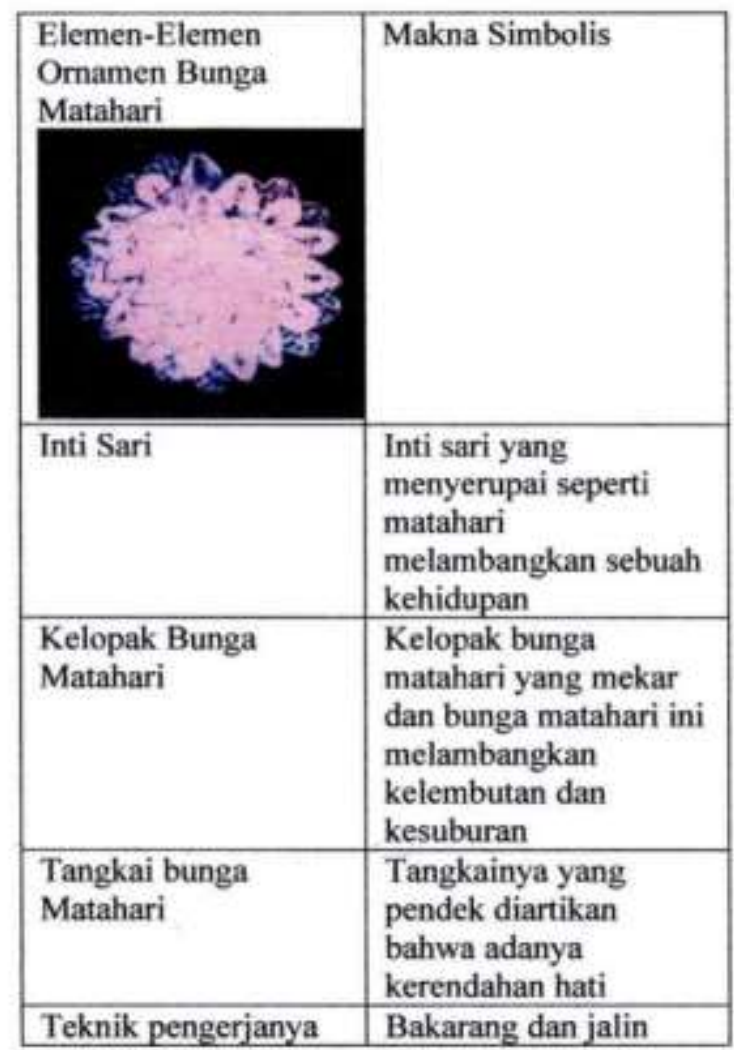

Ornamen bunga matahari yang diterapkan yaitu ide dasar penciptaan dari tumbuh- tumbuhan. Ornamen bunga matahari memiliki beberapa karakteristik diantaranyakelopak bunga, dan pada bagian tengahnya 
terdapat inti sari yang menyerupai matahari dengan begitu makna ornamen bunga matahari melambangkan adanya sebuah kehidupan. Adapun makna simbolis elemen ornamen bunga matahari yang melambangkan "kehidupan".

Tabel 4. Elemen Ornamen Daun

\begin{tabular}{|l|l|}
\hline $\begin{array}{l}\text { Elemen-Elemen } \\
\text { Ornamen } \\
\text { Daun }\end{array}$ & Makna Simbolis \\
\hline Daun Nangka & $\begin{array}{l}\text { Bros capung sebagai } \\
\text { asesoris kreasi bataro, } \\
\text { dan daun H, maka } \\
\text { capung tersebut akan } \\
\text { lebih terlihat sempurna, } \\
\text { indah dan menarik. }\end{array}$ \\
\hline Sayap Capung & $\begin{array}{l}\text { Penerapan ornamen } \\
\text { daun digunakan } \\
\text { sebagai pelengkap } \\
\text { hiasan menjadi } \\
\text { kesehimbang } \\
\text { kemenangan. }\end{array}$ \\
\hline
\end{tabular}

Ornamen daun yang digunakan kerajinan perak Koto Gadang menyerupai dari bentuk tumbuh-tumbuhan yang merambat. Adapun jenis daun yang digunakan hampir sama antara bentuk yang satu dengan bentuk yang lainnya. Penerapan ornamen daun digunakan sebagai pelengkap hiasan dari bentuk ornamen utama yang berfungsi untuk menambah keindahan yang terdapat pada ornamen utama serta sekaligus berfungsi sebagai pengisi bidang-bidang yang kosong.

Ornamen daun yang diterapkan kerajinan perak Koto Gadang tedapat dua jenis yaitu ornamen daun pelengkap bunga dan ornamen daun sebagai ping giran. Ornamen daun yang berfungsi sebagai pelengkap mempunyai 3 jenis yaitu daun runcing bercabang tiga, ornamen daun lebar, dan ornamen daun as am tumpul. Karakteristik jenis ornamen daun pelengkap keseluruhannya sama bercabang tiga, hanya perbedaannya terdapat pada ujung daun yang runcing dan tumpul, serta tangkainya ada yang halus dan berduri. Ornamen isian yang digunakan pengrajin perak Koto Gadang merupakan bentuk suatu goresan yang disebut dengan taro (garis gelombang). Penggambaran bentuk isian garis ini sebagai ornamen penghias dari bentuk ornamen utama, pelengkap dan sebagainya. fungsi penerapan ornamen isian ini untuk menambah keindahan dan kesempurnaan. Ornamen
Gorga : Jurnal Seni Rupa Volume 09 Nomor 02 Juli-Desember 2020 p-ISSN: 2301-5942 | e-ISSN: 2580-2380

isian merupakan hal yang paling penting untuk membuat suatu desain bentuk agar mendapatkan hasil yang menarik dan sempurna. Jenis garis dalam ornamen isian yang diterapkan pengrajin perak Koto Gadang yaitu berupa garis berlapis .

Tabel 5. Elemen Ornamen Bunga Mawar

\begin{tabular}{|l|l|}
\hline $\begin{array}{l}\text { Elemen-Elemen } \\
\text { Ornamen Bunga } \\
\text { Mawar }\end{array}$ & Makna Simbolis \\
\hline $\begin{array}{l}\text { Kelopak Bunga } \\
\text { Mawar }\end{array}$ & $\begin{array}{l}\text { Kelopak Bunga mawar } \\
\text { mekar melambangkan } \\
\text { adanya kelembutan }\end{array}$ \\
\hline $\begin{array}{l}\text { Tangkai bunga } \\
\text { mawar }\end{array}$ & $\begin{array}{l}\text { Inti sari ornamen bunga } \\
\text { mawar tertutup } \\
\text { melambangkan adanya } \\
\text { pendek } \\
\text { melambangkan adanya } \\
\text { suatu kesatuan }\end{array}$ \\
\hline $\begin{array}{l}\text { Teknik } \\
\text { pengerjanya }\end{array}$ & \begin{tabular}{l} 
Bakarang dan jalin \\
\hline
\end{tabular} \\
\hline
\end{tabular}

Ornamen bunga mawar merupakan jenis ornamen yang tercipta pada masa penjajahan setelah zaman Belanda. Pada saat itu ornamen bunga melati sering diterapkan oleh pengrajin terdahulu untuk membuat hiasan di berbagai s eni kerajinan. A wal terbentuknya penciptaan ornamen bunga melati ini karena adanya ikatan cinta antara budaya yang datang dan Koto Gadang, sebagai simbol penyatuan adat budaya yang menyatakan bahwa bunga melati sebagai perjanjian dalam menjalin kehidupan. Seperti halnya yang terdapat pada elemen bunga melati memiliki lambang keberanian dan cinta kasih. Keterkaitan antara makna cinta kasih dan bunga melati itu bermula pada saat terjalinnya hubungan ikatan pernikahan antara budaya yang menjadi satu kesatuan. Awalnya bunga melati digunakan untuk menyatakan suatu rasa. Dengan adanya hal tersebut maka, bunga melati sampai saat ini masih terus digunakan dalam penerapan ornamen diberbagai macam kerajinan khususnya kerajinan perak Koto Gadang.

\section{KESIMPULAN DAN SARAN}

\section{Kesimpulan}

Berdasarkan uraian yang dikemukakan dapat disimpulkan yaitu: Makna simbolis ornamen yang 


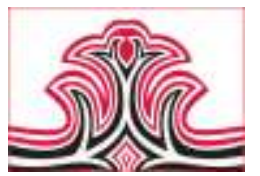

terkandung di dalam kerajinan perak Koto Gadang mengandung makna simbolis kehidupan yang dapat dilihat dari bentuk dan elemen-elemen pada setiap bagian ornamennya, bentuk bunga mawar melambangkan keberanian dan cinta kasih, bunga melati melambangkan kesucian hati, bunga matahari melambangkan adanya kehidupan, bunga lado/cabe juga melambangkan kejantanan, kekuatan, kekaisaran, kejayaan, kesuburan, burung merak melambangkan kegagahan, kemakmuran, kelembutan, bunga cengkeh melambangkan kemegahan, kebijaksanaan, dan kesetiaan sebagai simbol tangga penghubung antara dunia manusia dan dunia hewan, taro/isen-isen juga melambangkan penyatuan (jalan), kesuburan dan kehidupan yang bergerak dinamis, dan daun melambangkan pelengkap kehidupan.

\section{Saran}

Tulisan ini dapat dijadikan sebagai acuan untuk membuat buku muatan lokal sebagai bahan ajar pada sekolah tingkat dasar, menengah dan tingkat tinggi Selanjutnya tulisan ini dapat memberikan sumbangan pemikiran demi kelangsungan generasi anak kemenakan masyarakat Koto Gadang Kabupaten Agam, sesuai perkembangan ilmu dan teknologi Seiring dengan itu pengenalan dan pemahaman kerag aman fungsi dan makna symbol perhiasan, dapat diapresiasi oleh masyarakat luas. Muatan nilai-nilai yang terkandung dalam perhias an dapat dilestarikan sebagai konsep-konsep seni budaya tradisi sebagai kearifan lokall Minangkabau, khususnya di daerah Kabupaten Agam.

\section{DAFTAR RUJUKAN}

Budi, U. B. (1993). Sriwijaya dalam Perspektif Arkeologi dan Sejarah. Palembang: Pemerintah Daerah Tingkat I Sumsel.

Departemen Pendidikan Indonesia. (2011). Kamus

Besar Bahasa Indonesia. Jakarta: Balai Pustaka.

Fadjar, S., dan Prayitno, A. (1981). Desain Elementer Jurusan Seni. Yogyakarta: STSRI ASRI.

Moleong, L. J. (2011). Metodologi Penelitian Kualitatif Edisi Revisi. Cetakan Kedua Puluh Sembilan. Bandung: Remaja Rosdakarya.

Sobur, A. (2003). Semiotika Komunikasi. Bandung: Remaja Rosdakarya.

Soehadji. (1979). Desain Kerajinan dan Masalah. Jakarta: Paper Yang Dibacakan Pada Diskusi Panel Industri Kerajinan di Gedung Perintis Kemerdekaan.

Susanto, M. (2011). Diksi Rupa. Kumpulan Istilah dan Gerakan Seni Rupa. Yogyakarta: Dicti Art Log.
Gorga : Jurnal Seni Rupa

Volume 09 Nomor 02 Juli-Desember 2020 p-ISSN: 2301-5942 | e-ISSN: 2580-2380

Vera, N. (2014) .Semiotika dalam Riset Komunikasi. Bogor: Penerbit Ghalia Indonesia. 